\title{
DEVELOPING ISLAMIC BANKING PERFORMANCE MEASURES BASED ON MAQASID AL-SHARI'AH FRAMEWORK: CASES OF 24 SELECTED BANKS ${ }^{1}$
}

\author{
Mustafa Omar Mohammed ${ }^{2}$ \\ Fauziah Md Taib
}

\begin{abstract}
Islamic banking has achieved remarkable growth that has surpassed the growth of the conventional banking system. Yet, studies show that the performances of Islamic banks (IBS) seem to be trailing behind the conventional banks (CBS). Is the poor performance of IBs the result of mismatch between their objectives and their performance measurement criteria or it is a reflection of their true performances? The objectives of Islamic banking had not been formally addressed. Mustafa and Taib (2009) derived the objectives of Islamic banking from Abu Zahara's theory of the objectives of Shari'ah (Maqasid al-Shari'ah) and, based on these Shari'ah objectives, developed a model of Islamic banking performance measures. They named it as Performance Measures based on Maqasid al-Shari'ah framework or the PMMS model. This paper has tested the PMMS model on a sample 24 banks (12 IBs and 12 CBs). The twenty four banks were also evaluated using the traditional conventional financial measures. Mann-Whitney U-Test results show IBs faring well in their performances when measured using the PMMS model than when they are measured using the conventional banking performance yardstick. Policy prescriptions and recommendations for further studies are provided at the concluding section of the paper.
\end{abstract}

Key words: Maqasid al-shari'ah, operationalization, PMMS Model, Simple Additive Weighting (SAW), Mann-Whitney U-Test.

JEL Classification: A13, B59, C02, C6, C12, C19, C42, C43, G21, M21, P46, P47, P49

1 This paper was presented at the Nineth Australian Society of Heterodox Economists Conference, University of New South Wales, Sydney, Australia, 6-7 December 2010.

2 Mustafa Omar Mohammed is lecturer at International Islamic University Malaysia (mustafa@iium.edu.my); Fauziah Md Taib School is lecturer at Management, Universiti Sains Malaysia, 11800 USM Pulau Pinang (mfauziah@usm.my) 


\section{INTRODUCTION}

The first experiment of the modern Islamic banking is the Mit Ghamr bank in Egypt, established in 1963. This was followed by the establishment of the Dubai Islamic Bank in1975. Since then, the expansion and performance of Islamic banking have been remarkable despite operating in a competitive environment dominated by the conventional banking system. A study by the International Monetary Fund (2005) shows that the number of Islamic financial institutions increased from 75 in 1975 to more than 300 in 2005, spread across more than 75 countries globally. Another study showed that Islamic finance has been expanding at an annual rate of $15-20 \%$ (McKinsey, The World Islamic Banking Competitiveness Report 2007-08). The total assets managed by Islamic financial institutions were estimated to be between USD400 billion to USD500 billion in 2008 (Al-Amine, 2008) and the number exceeded USD 2 trillion in 2014 (Global Islamic Finance Forum 2014).

Malaysia's Islamic banking industry is another example of a success story. The industry was expected to capture $20 \%$ of the domestic market share by the year 2010 (Bank Negara Malaysia (BNM) website, 2008). The Malaysian Islamic capital and money markets are considered among the most developed in the Muslim world and Malaysia is considered to be the first country to issue the global Sukuk sovereign bond in 2002, valued at USD 600 million. (BNM website). With the launching of Malaysia International Islamic Financial Centre (MIFC) in August 2006 by BNM, Malaysia positioned itself as a platform for international Islamic financial hub (http://www.mifc.com)

Despite the encouraging growth and the great acceptance of Islamic financial products, studies have shown that on average Islamic banks seem to be trailing behind their conventional counter parts. It is widely known that Islamic banks operate on different principles and philosophies than that of the conventional banks. As such the very objectives of the establishment of the two types of banks are likely to be very different. Although the differences are widely regarded, there has been a notable absence of detail discussion on the subject matter leading to each type of banks' performance measurement. This does bring into fore some pertinent questions such as is the mimicking of the conventional banking and the dismal performance a reflection of 
Islamic banks' true poor performances or a result of mismatch between the objectives of Islamic banks and their performance measurements?

To address the issue we use Mustafa and Taib (2009) framework on the ideal objectives of Islamic banking from Abu Zahara's theory of Maqasid al-Shari'ah. The framework identifies the set of objectives of Islamic banks and subsequently developed suitable performance measurements from the identified objectives. They named this model as the PMMS model (Performance Measures based on Maqasid al-Shari'ah framework. The objective of this paper is to test the Mustafa and Taib (2009) framework's empirically using a sample of twenty four banks ( 12 Islamic and 12 conventional banks). It is expected that the findings could shed some lights into Islamic banks performance measurement and if the present practice of judging the two types of banks using the same yardsticks should continue or be modified accordingly.

The subsequent section of this paper, section two, provides an overview of the conventional banking versus the Islamic banking systems. The third section reviews the literatures on the objectives of Islamic banking, the theory of Maqasid al-Shari'ah and IB performance measures. Section four explains the research design and primarily focuses on the steps taken for testing the PMMS model. Section five presents the findings and discusses the results. The final section, six, concludes the study.

\section{OVERVIEW OF CONVENTIONAL BANKING VERSUS ISLAMIC BANKING}

Although there are some similarities between the Islamic and conventional banking, yet the two systems have fundamental differences. The philosophy, techniques, rules and regulations upon which the conventional system operates are based on human theories guided by reason. Furthermore, conventional banking is characterized by the debt structure (lending and borrowing) where money and debt are treated essentially as commodities that are easily bought and sold. Accordingly, the customer-bank relationship is defined in terms of debtor-creditor relationship. Furthermore, the system operates based 
on the interest rate mechanism, which is used, among others, as a policy variable and for pricing all financial products. The conventional banking system can operate purely for speculative purposes detached from the real sector.

Whereas the concept of Islamic banking is enshrined in the Shari'ah, which means that its origin is Divine. Therefore, the rules and regulation, techniques and the philosophy upon which the Islamic banking operates are governed by the Shari'ah and its objectives (alMaqasid). Similarly, in the development of Islamic banking theories, human reason is guided by al-Maqasid. Moreover, the Islamic banking system emphasizes the participatory modes of business ventures where risk and profit are shared, money and debts are not treated as commodities and the bank and the customer see each other as investor partners. The Islamic banking system deems interest as unlawful because it breeds injustice and exploitation. It also prohibits trading based on speculation and instead emphasizes trading based on the existence and ownership of assets. Thus, Islamic banking function is to facilitate the real sector and cannot be detached from the latter.

\section{REVIEW OF RELATED WORKS}

Hasan (2004) suggests that the performance of Islamic banks be evaluated, with reference to the objectives of their establishment. Objectives specify the activities of the organization, its performance and the measurable results that will allow the organization to know whether or not the objectives have been achieved (Wienclaw, Ruth A., 2008). Ideally, the objectives of Islamic banking must be reflected in economic development, creation of value added factor, increased exports, less imports and job creation, among others [Kamel, 1997]. Other views hold that Islamic banking objectives should enable banks to strive for a just, fair and balanced society; these objectives are community oriented and entrepreneur friendly emphasizing productivity and expansion in real economy; and they promote brotherhood and cooperation (Dusuki, 2005) citing (Chapra, 1985, 1992; Ahmad, 2000; Chapra, 2000a, 2000b; Siddiqui, 2001; and Naqvi, 2003). 
In practice, however, Islamic banking objectives have remained vague in the vision and mission statements of most Islamic banks and largely suggestive and normative in the writings of Muslim scholars. Accordingly, there are growing concerns that Islamic banking is converging towards the conventional banking to the extent that it has become another replica of the latter's system. The gap between the theory and practice of IBs is increasing (Tahir, 2007). Islamic banking is operating on conventional rules and regulations (Khan and Chapra, 2003). Islamic banking products mirror those available from conventional banks (Carla Power, 2009). Islamic banks look a lot like conventional finance in disguise. Rather, they are promoting conventional products as Islamic (El-Gamal, 2006). Al-Salamee (2006) opines that the entire structure of the present Islamic banking is debt based. It is a structure that is essentially based on lending and borrowing, treats money as a commodity, operates using the interest rate mechanism and defines the customer-bank relationship as debtorcreditor relationship.

Thus, this convergence is bound to happen in the absence of proper theoretical framework that links Islamic banking objectives to its operation and performance. Hence a study by Mustafa and Taib (2009) was very fundamental in documenting a theoretical framework of Islamic banking based on al-Maqasid.

Meanwhile, evidences in most studies using conventional yardsticks to measure the results of Islamic banks show Islamic banks trailing behind conventional banks. For example, Naqvi (2000) citing (IRTI, 1998) related to a survey of expert opinion on 30 major Islamic banks reveals dismal performance of Islamic banks. Mokhtar, et al. (2006) in their comparative study of full-fledged Islamic banks, Islamic windows and conventional banks in Malaysia for the period 19972003 conclude that full fledged Islamic banks were less efficient than the conventional banks. Samad (1999) conducted a study comparing between the efficiency of Islamic Bank (BIMB) and conventional banks in Malaysia. His result showed that conventional banks had higher managerial efficiency than the Islamic Bank of Malaysia. A study by Abd el Rahman, et al. (2003) to investigate the X-efficiency of Islamic banks in Sudan reveals that these banks suffered from technical inefficiency. Given the long list of studies citing IBs to be less efficient and less performing than their counterparts, one cannot help but 
wonder what has gone wrong? Is it true that IBs are less capable than CBs due to some constraints experienced under the Islamic banking settings? Or is it because the performance measurements used do not take into consideration the varying obligations or responsibilities expected out of IBs?

Section IV below discusses the research designed used in developing the PMMS model and testing it comparatively with the CBPM on a sample of 24 selected banks.

\section{RESEARCH DESIGN}

\subsection{Developing the PMMS Model}

Most studies have adopted the conventional yardsticks to measure their performance (Mokhtar, et al., 2006; Samad, 1999 and Abd el Rahman, et al., 2003). These conventional yardsticks are mostly uni-dimensional, focusing on financial measures. As stated earlier, Hasan (2004) suggests that the performance of Islamic banks be evaluated with reference to their social responsibilities in an Islamic framework. Recent attempts to develop Islamic banking performance measures have been scanty. See for example the works of Iqbal, Zafar, 2001; Hameed et al., 2005 and Dusuki, 2005. The work by Mustafa and Taib (2009) differs fundamentally from these previous works in the sense that it had developed the Islamic banking performance measures from the theory of Maqasid al-Shariah or the PMMS model, which focuses on more than one dimensions of performance. The performance measures used are reflective of the responsibilities and obligations expected out of IBs. The following five steps are summary of how Mustafa and Taib (2009) developed the PMMS model:

Step1: From the literature and Shari'ah sources, they have identified the general and specific objectives of Shari'ah. There is consensus among Muslim scholars that there are two general objectives of the Shari'ah: promotion of total welfare and prevention of harm. These two general objectives make Shari'ah a universal concept in a sense that whatever an individual undertakes, if it serves these two general objectives, then it is in line with the Shari'ah. 
As far as the specific objectives of the Shari'ah is concerned, there are slight variations in the theories developed by the Muslim scholars. This study adopts Abu Zaharah's (1997) theory of al-Maqasid because it is broad and all encompassing. The following are the three broad objectives that constitute Abu Zaharah's theory:

1. Tahdhib al-Fard (Educating the individual)

2. Iqamah al-'Adl (Establishing justice)

3. Jalb al-Maslahah (Promotion of public interest)

The term Tahdhib in the first objective denotes the dissemination of knowledge and skill as well as instilling in the individual values for his spiritual development. As such, Islamic banks must design educational and training programs that should develop knowledgeable and skillful workforce imbued with proper moral values. They must also disseminate information that would inform their stakeholders about their products.

In the second objective - Justice, Islamic banks must ensure fair dealings in all its business activities, which include its products, pricing and contract terms and conditions. It must also ensure that all its business ventures are free from negative elements that may create injustices, such as riba (including interest), fraud, corruption, etc. Indirectly, the bank should wisely use its profits and direct its activities towards those vital areas that can help reduce income and wealth inequalities and encourage wealth circulation and distributive equity.

With regard to the third objective, Maslahah or public interest, Islamic banks should give priorities to business activities that generate greater benefits to the general public. These include activities in areas related to the basic needs of the public such as investments in vital sectors, financing of housing projects, etc.

The three objectives, namely education, justice and Maslahah constitute Maqasid, and hence all the four are the building block of the PMMS model or Performance Measures based on Maqasid alShari'ah framework.

Step 2: the authors used the operationalization method in behavioral science to translate the three objectives [education, justice and Maslahah] into observable and measurable elements. Using Sekaran's 
method (2000), the three (3) broad objectives, namely educating individuals, establishing justice and Maslahah were operationally defined. Each of the objective or concept (c) was first translated into broad characteristics or dimensions (D) and then finally into measurable behaviors or elements (E). Accordingly, based on the literature, the three (3) broad objectives were translated into nine dimensions and ten elements, which are measured individually by the corresponding ten ratios derived from the annual reports of the respective sample banks. Below is the general framework of the operationalization processes.

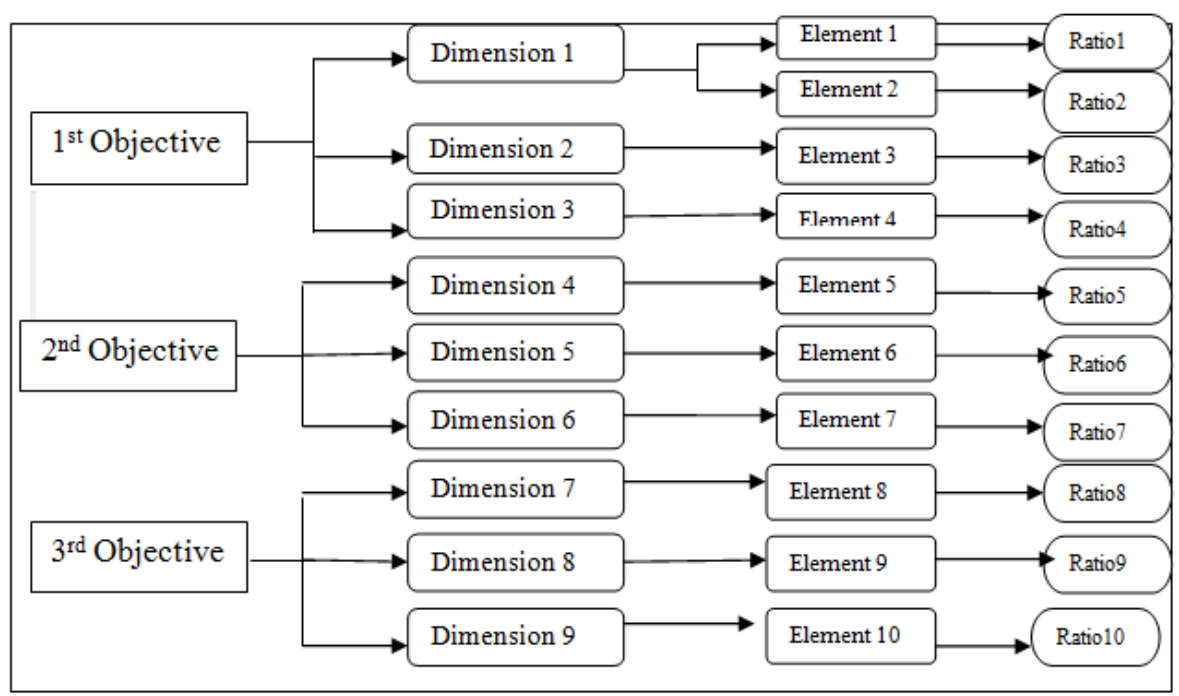

Source: Mustafa and Taib (2009)

Figure 1.

Operationalization of Al-Maqasid: General Framework

Table 1 below shows the actual operationalization of the three Shari'ah objectives in relation to the objectives of Islamic banking (Mustafa and Taib, 2009). 
Table 1.

\section{Operationalizing The Objectives of Islamic Banking}

\begin{tabular}{|c|c|c|c|c|}
\hline $\begin{array}{c}\text { Concepts } \\
\text { (Objectives) }\end{array}$ & Dimensions & Elements & $\begin{array}{c}\text { Performance } \\
\text { Ratios } \\
\end{array}$ & $\begin{array}{l}\text { Sources } \\
\text { of Data }\end{array}$ \\
\hline \multirow{4}{*}{$\begin{array}{l}1 . \\
\text { Educating } \\
\text { Individual }\end{array}$} & \multirow[t]{2}{*}{$\begin{array}{l}\text { D1.Advancement } \\
\text { Of Knowledge }\end{array}$} & $\begin{array}{l}\text { E1.Education } \\
\text { grant }\end{array}$ & $\begin{array}{l}\text { R1. Education grant } \\
\text { or scholarship/ Total } \\
\text { Expenses }\end{array}$ & $\begin{array}{l}\text { Annual } \\
\text { Report }\end{array}$ \\
\hline & & E2.Research & $\begin{array}{l}\text { R2. Research Exp/ } \\
\text { Total Expenses }\end{array}$ & $\begin{array}{l}\text { Annual } \\
\text { Report }\end{array}$ \\
\hline & $\begin{array}{l}\text { D2. Instilling new } \\
\text { skills and } \\
\text { improvements }\end{array}$ & E3.training & $\begin{array}{l}\text { R3. Training Exp/ } \\
\text { Total Expenses }\end{array}$ & $\begin{array}{l}\text { Annual } \\
\text { Report }\end{array}$ \\
\hline & $\begin{array}{l}\text { D3. Creating } \\
\text { Awareness of } \\
\text { Islamic banking }\end{array}$ & E4.Publicity & $\begin{array}{l}\text { R4. Publicity Exp/ } \\
\text { Total expenses }\end{array}$ & $\begin{array}{l}\text { Annual } \\
\text { Report }\end{array}$ \\
\hline \multirow[t]{3}{*}{$\begin{array}{l}2 . \\
\text { Establishing } \\
\text { Justice }\end{array}$} & D4. Fair returns & E5. Fair Returns & $\begin{array}{l}\text { R5. Profit } \\
\text { Equalization } \\
\text { Reserves (PER) /Net } \\
\text { or Investment } \\
\text { Income }\end{array}$ & $\begin{array}{l}\text { Annual } \\
\text { Report }\end{array}$ \\
\hline & $\begin{array}{l}\text { D5.cheap product } \\
\text { and services }\end{array}$ & $\begin{array}{l}\text { E6. Functional } \\
\text { distribution }\end{array}$ & $\begin{array}{l}\text { R6 .Mudarabah* } \\
\text { and Musharakah* } \\
\text { Modes/Total } \\
\text { Investment Modes }\end{array}$ & $\begin{array}{l}\text { Annual } \\
\text { Report }\end{array}$ \\
\hline & $\begin{array}{l}\text { D6. Elimination of } \\
\text { negative elements } \\
\text { that breed injustices }\end{array}$ & $\begin{array}{l}\text { E7. Interest } \\
\text { free } \\
\text { product }\end{array}$ & $\begin{array}{l}\text { R7. Interest free } \\
\text { income /Total } \\
\text { income }\end{array}$ & $\begin{array}{l}\text { Annual } \\
\text { Report }\end{array}$ \\
\hline \multirow{3}{*}{$\begin{array}{l}\text { 3. } \\
\text { Maslahah }\end{array}$} & $\begin{array}{l}\text { D7. Profitability of } \\
\text { bank }\end{array}$ & E8. Profit ratios & $\begin{array}{l}\text { R8. Net } \\
\text { income/Total assets }\end{array}$ & $\begin{array}{l}\text { Annual } \\
\text { Report }\end{array}$ \\
\hline & $\begin{array}{l}\text { D8. Redistribution of } \\
\text { income \& wealth }\end{array}$ & $\begin{array}{l}\text { E9. personal } \\
\text { income }\end{array}$ & $\begin{array}{l}\text { R9. Zakah* } \\
\text { paid/Net Asset }\end{array}$ & $\begin{array}{l}\text { Annual } \\
\text { Report }\end{array}$ \\
\hline & $\begin{array}{l}\text { D9. Investment in } \\
\text { vital real sector }\end{array}$ & $\begin{array}{l}\text { E10. Invest- } \\
\text { ment } \\
\text { ratios in } \\
\text { real sector } \\
\end{array}$ & $\begin{array}{l}\text { R10. Investment in } \\
\text { real economic } \\
\text { sector/ Total } \\
\text { Investment }\end{array}$ & $\begin{array}{l}\text { Annual } \\
\text { Report }\end{array}$ \\
\hline
\end{tabular}

From Table 1 above, for example, Islamic bank can achieve the 1st Objective of Educating Individual through three dimensions (D1, D2 and D3), which are the advancement of knowledge, instilling new skills and improvements and, creating awareness about Islamic banking and its products respectively. These three dimensions are measured by four elements, namely E1, E2, E3 and E4. The advancement of knowledge (D1) can be measured through educational grants or scholarships (E1) and through Research activities (E2). Similarly, instilling new skills and improvements (D2) is measured through training (E3) and creating awareness (D3) is measured through publicity (E4). Finally, each of the ten elements is measured by their corresponding ratios (R1 to R10). For example, E3 is measured by 
the Training Expenses/Total Expenses ratio. Step 4 below reproduces the ten ratios that were identified by Mustafa and Taib (2009).

Step 3: The PMMS model developed were sent to Shari'ah experts from the Middle East and Malaysia who are well versed in both the Islamic and conventional banks for verification. Twelve experts were interviewed and sixteen were requested to assign weights to the components and to determine whether the performance measures are acceptable. The averages weights given by the experts are presented in Table 2 below:

Table 2.

Average Weights for The Three Objectives and Ten Elements Given by Shari'ah Experts

\begin{tabular}{|c|c|c|c|}
\hline Objectives & $\begin{array}{l}\text { Average } \\
\text { Weight } \\
\text { (Out of 1) }\end{array}$ & Elements & $\begin{array}{l}\text { Average } \\
\text { Weight } \\
\text { (Out of } 1 \text { ) }\end{array}$ \\
\hline \multirow{5}{*}{$\begin{array}{l}\text { O1. Education } \\
\text { (Tahdhib al-Fard) }\end{array}$} & \multirow{5}{*}{.30} & E1. Education Grants/Donations & .24 \\
\hline & & E2. Research & 27 \\
\hline & & E3. Training & .26 \\
\hline & & E4. Publicity & 23 \\
\hline & & Total & 1 \\
\hline \multirow{4}{*}{$\begin{array}{l}\text { O2. Justice } \\
\text { (Al-'Adl) }\end{array}$} & \multirow{4}{*}{.41} & E5. Fair Returns & .30 \\
\hline & & E6. Fair Price & .32 \\
\hline & & E7. Interest free product & 38 \\
\hline & & Total & 1 \\
\hline \multirow{3}{*}{$\begin{array}{l}\text { O3. Public Interest } \\
\text { (Al-Maslahah)** }\end{array}$} & \multirow{3}{*}{.29} & E8. Bank's Profit Ratios & .33 \\
\hline & & E9. Personal Income Transfers & 30 \\
\hline & & $\begin{array}{l}\text { E10. Investment Ratios in real } \\
\text { sector }\end{array}$ & .37 \\
\hline Total & 1 & Total & 1 \\
\hline
\end{tabular}

* Maslahah includes the bank's interest plus the public interest

From Table 2 above, the Shari'ah experts assigned the highest weight to the Shari'ah objective for Justice (0.41), followed by weight to the Shari'ah objective for Education (0.30) and finally the weight to the Shari'ah objective for Maslahah (0.29). The experts also assigned weights to the various elements corresponding to the respective 
Shari'ah objectives. Besides assigning the weights, the questionnaires also solicited from the respondents any comments that would enhance the understanding of Maqasid approach to the objectives of Islamic banking and its performance measures. The idea of soliciting the comments is to obtain feedback from the respondents whether the PMMS model developed is at the acceptable level to measure the objectives and performances of Islamic banks. Eleven (roughly 70\%) of the sixteen respondents did not provide any comments. Thus it is assumed that the majority of the Shari'ah experts was satisfied with the structure of the model and considers it acceptable.

Step 4: After the PMMS model was verified and validated by the Shari'ah experts, the authors identified the following ten ratios ( $\mathrm{R} 1$ to R10) corresponding to each element in the model.

1. Education grant/total expenses $\left(R_{1}^{1}\right)$

2. Research expense/total expense $\left(R_{1}^{2}\right)$

3. Training Expense/total expense $\left(R_{1}^{3}\right)$

4. Publicity expense/total expense $\left(R_{1}^{4}\right)$

5. (Profit equalization reserves/ net or investment income $\left(R_{2}^{1}\right)$

6. Mudarabah and Musharakah modes/total investment modes $\left(R_{2}^{2}\right)$

7. Interest free income/total income $\left(R_{2}^{3}\right)$

8. Net income/total asset $\left(R_{3}^{1}\right)$

9. Zakah paid/net asset $\left(R_{3}^{2}\right)$

10. Investment in real economic sector/total investment $\left(R_{3}^{3}\right)$

\section{$1^{\text {st }}$ Objective}

Four ratios (R1 to R4), namely Education grant or scholarship/ Total Expenses; Research Exp/Total Expenses; Training Exp/Total Expenses and Publicity Exp/Total expenses were assigned as measures for the four elements of the first Shari'ah objective (Educating Individual). Hence, the higher the budget that the bank allocates for these four indicators, the more the bank is concerned about achieving educating individuals in its program. This is also good for the bank to enhance the quality of its human resource and at the same time work towards creating informed customers about its objectives and product. 


\section{$2^{\text {nd }}$ Objective}

Three ratios (R5 to R7), namely (Profit Equalization Reserves (PER) /Net or Investment Income), Mudarabah and Musharakah Modes/Total Investment Modes, Interest free income /Total income are identified for measuring three elements of the second Shari'ah objective (Establishing Justice). When banks set aside the PER, they deny the previous depositor their rights to the profit, which is a form of injustice. The PER ratio is in the parenthesis because it is subtracted from 1 . Therefore as the ratio value moves towards 1 , it means less reserve are allocated for PER. The value 1 means no reserve are allocated for PER. Hence high (1 - PER) ratio means the bank is moving towards achieving the higher level of justice. On the other hand, high ratio of Interest free income to total income contributes positively towards minimizing the income and wealth disparity, since interest basically transfers wealth from the poor to the rich. Similarly high Mudarabah and Musharakah modes ratio means the bank is improving in its objective towards socio-economic justice.

\section{$3^{\text {rd }}$ Objective}

Lastly, three ratios (R8 to R10) were selected for measuring three elements of the third Shari'ah objective - Maslahah. They are net income/total asset ratio, Zakah/net asset ratio and investment in real economic sector/ total investment ratio. High net income/total asset ratio shows higher profitability of the bank and thus its ability to contribute to the government budget for more developmental projects and for social services, which in turn increases the welfare of the public. Similarly, high Zakah net asset ratio shows transfer of income and wealth to the poor and the needy, thereby helping to bridge the inequality gap. Meanwhile investment in real economic sector/ total investment ratio refers to the number of vital sectors in which the banks invest in. Here, the importance is given to those real economic sectors that have direct implications to the wider population, especially those in the rural areas. Such sectors include agriculture, mining, fisheries, construction, manufacturing and small and medium scale businesses. Therefore, higher investment in real economic sector/ total investment ratio implies wider sphere of public interest. Hameed et al. 
(2004) confined his sectorial investment ratio to only two banking products, namely Mudarabah and Musharakah.

The 10 performance ratios were chosen based on the following criteria:

- Discussion on the objectives of Islamic banking and on the dimensions and elements identified from these objectives.

- Past similar research using the same ratios for measuring performance of Islamic and conventional banks (al-Osaymy et al., 2004; Shahul Hameed et al., 2004; Akkas, 1996).

- Statistical conveniences in relation to the source of data (Annual reports) and the research method (Multi Attribute Decision Making) - (Hwang and Yoon, 1981)

- Accurate possible representation of the conceptual level of Maqasid al-Shari'ah, though not necessarily exhaustible.

The data for the ten performance ratios were then derived from the annual reports of twenty four sample banks (12 Islamic and12 conventional). The data were aggregated for 6 years period (2000 2005).

Step 5: With a complete set of data obtained for the PMMS components: objectives, elements and ratios, the Simple Additive Weighting Method (SAW) - (Hwang and Yoon, 1981) was utilized for the weighting, aggregating and ranking processes. That is, for every individual bank, each ratio is multiplied by the corresponding weight of its element and the weight of its corresponding objective. The products are then added up to constitute the Weighted Ratio (WR) for every Objective. Hence mathematically, the evaluation of the individual Islamic banking objectives was computed as below, where the Weighted Ratio (WR) for Objective 1 is denoted by WR (O1).

$$
\begin{aligned}
& \text { WR }(\mathrm{O} 1)=W_{1}^{1} \times E_{1}^{1} \times R_{1}^{1}+W_{1}^{1} \times E_{1}^{2} \times R_{1}^{2}+W_{1}^{1} \times E_{1}^{3} \times R_{1}^{3}+ \\
& W_{1}^{1} \times E_{1}^{4} \times R_{1}^{4} \\
& \mathrm{OR} W_{1}^{1}\left(E_{1}^{1} \times R_{1}^{1}+E_{1}^{2} \times R_{1}^{2}+E_{1}^{3} \times R_{1}^{3}+E_{1}^{4} \times R_{1}^{4}\right)
\end{aligned}
$$


Where,

(O1) denotes the $1^{\text {st }}$ Shari'ah Objective, i.e., Tahdhib al-Fard (Education)

$W_{1}^{1}$ is the weight (0.30) assigned to (O1) (see Table 2 above)

$E_{1}^{1}$ denotes the weight (0.24) assigned to the first element of (01) (see Table 2 above)

$E_{1}^{2}$ denotes the weight (0.27) assigned to the second element of (O1) ( see Table 2 above)

$E_{1}^{3}$ denotes the weight (0.26) assigned to the third element of (01) ( see Table 2 above)

$E_{1}^{4}$ denotes the weight (0.23) assigned to the fourth element of (O1) ( see Table 2 above)

$R_{1}^{1}$ denotes the ratio corresponding to the first element of $(\mathrm{O} 1)$, derived from the annual report

$R_{1}^{2}$ denotes the ratio corresponding to the second element of (O1), derived from the annual report

$R_{1}^{3}$ denotes the ratio corresponding to the third element of $(\mathrm{O} 1)$, derived from the annual report

$R_{1}^{4}$ denotes the ratio corresponding to the fourth element of $(\mathrm{O} 1)$, derived from the annual report

The same process is repeated for Weighted Ratio (WR) for Objective 2 [WR (02)] and Weighted Ratio (WR) for Objective 3 [WR (03)].

The total overall Weighted Ratio (WR) for the three Shari'ah objectives for each bank constitutes its individual Maqasid Index (MI). Thus,

$$
\mathrm{Ml}=\mathrm{WR}(\mathrm{O} 1)+\mathrm{WR}(\mathrm{O} 2)+\mathrm{WR}(\mathrm{O} 3)
$$

In other words, the Maqasid Index (MI) for the individual bank is the sum of its weighted ratios in respect to Objective 1, Objective 2 and Objective 3. 
Therefore, WR (01) = Education, WR (02) = Justice and WR (02) = Maslahah. Furthermore, the sum of the weights for Education, Justice and Welfare = Maqasid Index. Hence, the main components of measures for the PMMS model are four: Education, Justice, Welfare and Maqasid Index.

\subsection{Testing the PMMS and CBPM}

a. The PMMS model was then tested on the twenty four sample banks. The data for the four main components of the PMMS model, namely Education, Justice and Public interest or Maslahah, were keyed in and analyzed using the SPSS computer software.

b. Three ratios for conventional banking performance measures (CBPM) were derived from the annual reports of the 24 sample banks (Islamic and conventional). The data were aggregated for 6 years period (2000 - 2005). The three ratios are: 1) Return on Assets (ROA), 2) Net Interest Income (NII) and 3) Liquidity (LIQ).

c. The CBPM was then tested on the same sample of the 24 banks. The data for the three main components of the CBPM model, namely ROA, NII and LIQ, were keyed in and analyzed using the SPSS computer software.

Due to the small sample size, the authors have used the two independent samples Mann-Whitney U-test to examine whether the mean of the two samples are statistically significant. The MannWhitney U-test was conducted for the main components of the PMMS model, namely Maqasid Index and the three Shari'ah objectives (Education, Justice and Maslahah) and, for three ratios in the CBPM model: Return on Asset (ROA), Net Interest Income (NII) and Liquidity (LIQ).

In the Mann-Whitney U-test, it is presumed that the performances for Islamic banks measured using the PMMS model would rank higher for the Maqasid Index and the three Shari'ah objectives than the performances of conventional banks. In contrast, it is presumed that the performances for Islamic banks measured using the CBPM model would rank lower for the ROA, NII and LIQ than the 
performances of conventional banks. Since the U-test is a one-tailed test, the null and alternative hypotheses are stated as follows:

$\mathrm{HO}$ : The mean ranks for Islamic banks measured using the PMMS model would be more than the mean ranks for conventional banks for Maqasid Index and the three Shari'ah objectives.

$\mathrm{H} 1$ : The mean ranks for Islamic banks measured using the PMMS model would be less than the mean ranks for conventional banks for Maqasid Index and the three Shari'ah objectives.

$\mathrm{HO}$ : The mean ranks for Islamic banks measured using the CBPM model would be less than the mean ranks for conventional banks for ROA, NII and LIQ.

$\mathrm{H} 2$ : The mean ranks for Islamic banks measured using the CBPM model would be more than the mean ranks for conventional banks for ROA, NII and LIQ.

Where $u 1, u 2, u 3, u 4, u 5, u 6$ and $u 7$ represent the mean ranks (mean degree of importance) for the Shari'ah objective for Education, the Shari'ah objective for Justice, the Shari'ah objective for Maslahah, Maqasid Index, ROA, NII and LIQ respectively. The results are presented in Table 3 below.

\section{RESULTS AND DISCUSSION}

This section presents and discusses the results of the tests from the two models, PMMS and CBPM. 
Table 3.

\section{Mann-Whitney U-test of Association Between Each Component of The Two Models (PMMS and CBPM) and The Mean Ranks for The Two Groups of Banks}

\begin{tabular}{|c|c|c|c|c|c|c|c|}
\hline No. & $\begin{array}{c}\text { Shari'ah } \\
\text { Objectives/ } \\
\text { Maqsid Index }\end{array}$ & Bank type & $\mathrm{N}$ & $\begin{array}{l}\text { Mean } \\
\text { Rank }\end{array}$ & U Value & Z value & $\begin{array}{l}\text { Proba- } \\
\text { bility } \\
\text { (1-tailed) }\end{array}$ \\
\hline \multirow[t]{2}{*}{1} & \multirow[t]{2}{*}{ Education } & Islamic & 12 & 15.46 & \multirow[t]{2}{*}{$U_{1}=36.500$} & \multirow[t]{2}{*}{-2.053} & \multirow[t]{2}{*}{0.039} \\
\hline & & Conventional & 12 & 9.54 & & & \\
\hline \multirow[t]{2}{*}{2} & \multirow[t]{2}{*}{ Justice } & Islamic & 12 & 18.50 & \multirow[t]{2}{*}{$U_{2}=0.000$} & \multirow[t]{2}{*}{-4.157} & \multirow[t]{2}{*}{0.000} \\
\hline & & Conventional & 12 & 6.50 & & & \\
\hline \multirow[t]{2}{*}{3} & \multirow[t]{2}{*}{ Maslahah } & Islamic & 12 & 14.75 & \multirow[t]{2}{*}{$U_{3}=45.000$} & \multirow[t]{2}{*}{-1.559} & \multirow[t]{2}{*}{0.128} \\
\hline & & Conventional & 12 & 10.25 & & & \\
\hline \multirow[t]{2}{*}{4} & \multirow{2}{*}{$\begin{array}{l}\text { Maqasid } \\
\text { Index (MI) }\end{array}$} & Islamic & 12 & 18.50 & \multirow[t]{2}{*}{$U_{4}=0.000$} & \multirow[t]{2}{*}{-4.158} & \multirow[t]{2}{*}{0.000} \\
\hline & & Conventional & 12 & 6.50 & & & \\
\hline \multirow[t]{2}{*}{5} & \multirow[t]{2}{*}{ ROA } & Islamic & 12 & 8.67 & \multirow[t]{2}{*}{$U_{5}=26.000$} & \multirow[t]{2}{*}{-2.656} & \multirow[t]{2}{*}{0.007} \\
\hline & & Conventional & 12 & 16.33 & & & \\
\hline \multirow[t]{2}{*}{6} & \multirow[t]{2}{*}{$\mathrm{NII}$} & Islamic & 12 & 8.92 & \multirow[t]{2}{*}{$U_{6}=29.000$} & \multirow[t]{2}{*}{-2.486} & \multirow[t]{2}{*}{0.012} \\
\hline & & Conventional & 12 & 16.08 & & & \\
\hline \multirow[t]{2}{*}{7} & \multirow[t]{2}{*}{ LIQ } & Islamic & 12 & 15.25 & \multirow[t]{2}{*}{$U_{7}=39.000$} & \multirow[t]{2}{*}{-1.906} & \multirow[t]{2}{*}{0.060} \\
\hline & & Conventional & 12 & 9.75 & & & \\
\hline
\end{tabular}

From Table 3 above, it is evident that the performances for Islamic banks measured using the PMMS model rank higher for the Maqasid Index and the three Shari'ah objectives than the performances of conventional banks. The $Z$ values for Maqasid Index, the Shari'ah objective for Justice and the Shari'ah objective for Education are $-4.158,-4.157$ and -2.053 , respectively, with their significance levels of $p=0.000, p=0.000$, and $p=0.039$, respectively. The three probability values ( $p$ ) for Maqasid Index, the Shari'ah objective for Justice and the Shari'ah objective for Education are less than 0.05 . Therefore, the three results are significant. Hence, the null hypothesis that the mean ranks for Islamic banks measured using the PMMS model would be more than the mean ranks for conventional banks for Maqasid Index and the Shari'ah objective for Justice and the Shari'ah objective for Education can be accepted. These variations in the mean ranks are likely to hold in the population, since the observed probabilities $(0.000$ and 0.039$)$ are lower than the 0.05 significant levels. Therefore, it can be inferred from the results that the performances for Islamic banks measured using the PMMS model rank higher for the Maqasid Index and the two Shari'ah objectives than the performances of conventional banks. 
Meanwhile the $Z$ value for the Shari'ah objective for Maslahah is -1.559 with a significance level of $p=0.128$. The probability value $(p)$ for the Shari'ah objective for Maslahah is not less than or equal to 0.05. Therefore, the result is not significant.

On the other hand, Table 3 shows that although the mean ranks for Islamic banks measured using the PMMS model are higher than the mean ranks for conventional banks for the Shari'ah objective for Maslahah, the probability value ( $p$ ) for this objective is not less or equal to 0.10 . Therefore, the result is not significant except at a slightly higher level of significance than 10 . Moreover, the variations in the mean ranks are not likely to hold in the population, since the observed probabilities (0.128) are higher than the 0.10 significant levels.

Furthermore, the findings in Table 3 reveal that the performances of Islamic banks measured using the CBPM model are lower than the performances of conventional banks for the ROA and NII. The $Z$ values for ROA and NII are- 2.656 and -2.486 respectively. The probability values $(p)$ for ROA and NII are less than 0.05 . Therefore, the results are significant. Hence, the null hypothesis that the mean ranks for Islamic banks measured using the CBPM model would be less than the mean ranks for conventional banks for ROA and NII can be accepted. These variations in the mean ranks are likely to hold in the population, since the observed probabilities of 0.007 and 0.012 are lower than the 0.05 significant levels. Therefore, it can be inferred from the results that the performances for Islamic banks measured using the CBPM model rank lower for the ROA and NII than the performances of conventional banks.

On the other hand, the Table shows that the performances for Islamic banks measured using the CBPM model rank higher for the LIQ than the performances of conventional banks. The $Z$ value for $L I Q$ is 1.906. The probability value (p) for LIQ is less than 0.10 . Therefore, the result is significant. Hence, the null hypotheses that the mean ranks for Islamic banks measured using the CBPM model would be less than the mean ranks for conventional banks for LIQ are rejected. The variations in the mean ranks for LIQ are likely to hold in the population, since the observed probabilities (0.060) are lower than the 
0.10 significant levels. Thus, the findings reveal that Islamic banks have higher liquidity ratios compared to the conventional banks.

In summary, the tests using the two models have shown significant differences in the performances of the two types of banks. The performances of Islamic banks are remarkably good when measured using the PMMS model compared to when they are measured using the CBPM model. This conclusion goes against the orthodox view that Islamic banks in reality perform badly compared to their conventional counterparts (Abd el Rahman, et al., 2003; Samad, 1999; Mokhtar, et al., 2006 and Naqvi, 2000). In fact, the result of the study by Samad (2004) using cost-profit factors did not find any difference in the performances of Islamic banks and conventional banks sampled in Bahrain. Commenting on Samad (2004), Hasan (2004) concludes that the conventional yardstick used by Samad (2004) to measure the performance of Islamic banks was at the expense of the main purpose of their establishment.

\section{Sensitivity Analysis}

Sensitivity analysis has been conducted in this study at two levels. In the first level all the ten ratios have been scaled on the total assets as a denominator. This is done in order to overcome possible biases that originate from the use of different scaling for different variables. The second level test has been done as treatment for missing data. The authors have identified three main reasons for the missing data. Some banks in the sample did not disclose their data in separate accounts although they have highlighted the activities while there are banks who do not report the data because they have chosen voluntarily not to practice the activities. Finally the banks concerned could not disclose their data because the activities are not applicable to them. For example, Zakat and interest free income are not applicable to conventional banks. Similarly, tax is not applicable to most banks in the rich Arab Gulf countries. The results of the sensitivity analysis have not departed significantly from the results of the Mann-Whitney UTest related to the two models, PMMS and CBPM compared. 


\section{CONCLUSION}

The greatest significance of this study is that it proposes the objectives of Islamic banking from the Maqasid al-Shari'ah perspective. It has also suggested a methodology that could be used to develop Islamic banking performance measures based on the Shari'ah framework.

This study has gone against the main trends and has instead attempted to demonstrate that there exists a mismatch between the objectives of Islamic banks and the conventional yardstick used to measure the performances of these Islamic banks. This mismatch is also the main reason for the poor judgment about the dismal performances of Islamic banks. One of the most important implications for this study is that so long as Islamic banks operate on conventional rules and regulations they will be seen as lagging behind. There is a need for the policy makers, regulators, scholars and bankers to push for a change away from conventional rules and regulations. Instead, Islamic banks must move towards Maqasid al-Shari'ah, which allow them to identify their objectives and measure their performances based on the Shari'ah. 


\section{REFERENCES}

Abd el Rahman E.S, Rosly A., Mansor H.I and Naziruddin A. (2003). The X-Efficiency of the Sudanese Islamic Banks. IIUM Journal of Economics and Management, 2(2), 123-141.

Abu Zaharah, Muhammad. (1997). Usul al-Fiqh. Cairo: Dar al-Fikr al'Arabi.

Al-Amine M. al-Bashir. (2008). Sukuk Market: Innovation and Challenges. Islamic Economics Studies, 15(2). Retrieved December 5, 2009, from http://www.irti.org.

Al-Salamee, M. Mohammad. (2006, November). ARABIC TITLE [Difference of opinions and Fatawi in Shari'ah Rulings: Its effect on the financial industry]. Paper presented at The International Shariah Dialogue Seminar organized by Bank Negara Malaysia, Marriott hotel, Putra Jaya, Malaysia.

Akkas, Ali S.M. (1996). Relative Efficiency of Conventional and Islamic Banking Systems in Financing Investment. PhD Thesis, Dhaka University.

Al-Osaimy, H. Mahmood and Bamakhramah, S. Ahmed. (2004). An Early Warning System for Islamic Banks Performance. Islamic Economics, 17(1), 3-14.

Power, Power. (2009). Faith in the Market. Retrieved from http://www.foreignpolicy.com/story/cms.php?story_id=4596\&pri $\mathrm{nt}=1$

Dusuki, Asyraf W. (2005). Corporate Social Responsibility of Islamic Banks in Malaysia: A Synthesis of Islamic and Stakeholders' Perspectives. PhD Thesis, Loughborough University.

El-Gamal, A. Mahmoud. (2006). Islamic Finance: Law, Economics and Practice. NY: Cambridge University Press.

Global Islamic Finance Forum. (2014). Keynote Address of Governor presented at the Global Islamic Finance Forum, Bank Negara Malaysia, Kuala Lumpur. 
Hameed Shahul, Sigit Pramano, Bakhtiar Alrazi and Nazli Bahrom. (2004, April). Alternative Performance Measures for Islamic Banks. Paper presented at the 2nd International Conference on Administrative Sciences, King Fahd University of Petroleum and Minerals, Saudi Arabia.

Hasan, Zubair. (2004). Measuring the Efficiency of Islamic Banks: Criteria, Methods and Social Priorities. Review of Islamic Economics, 8(2), 5-30.

Hwang, Ching-Lai and Yoon, Kwangsun. (1981). Lecture Notes in Economics and Mathematical Systems. New York: SpringVerlag.

Iqbal, Zafar. (2001). Profit and Loss Sharing Ratios: A Holistic Approach to Corporate Finance. International Journal of Islamic Financial Services, 3(2).

Kamel, Saleh. (1997). Development of Islamic Banking Activity: Problems and Prospects. IDB Prize Winners' Lecture Series No.12. Jeddah.

Khan, Tariqullah and Chapra, M. Umer. (2003). Regulations and Supervision of Islamic Banks. Islamic Research and Training Institute, Islamic Development Bank. Jeddah.

Mokhtar, H.S Ahmad, Abdullah N. and Al-Habshi, M. Syed. (2006). Efficiency and Competition of Malaysian Islamic Banking. Paper presented at the 2nd Banking and Finance.

Mustafa, O. M. and Taib, Fauziah Md. (2009, August). The Objectives, operation and Performance of Islamic Banking Based on The Maqasid Framework. Paper presented at the Insaniah-IRTI International Conference on Islamic Economics, Banking and Finance 2009, Malai Porto Hotel, Lankawi, Kedah.

Naqvi, Syed N. Haider. (2000). Islamic Banking: An Evaluation. IIUM Journal of Economics and Management, 8(1), 41-70.

Samad, Abdul. (1999). Comparative Efficiency of the Islamic Banks visà-vis Conventional Banks in Malaysia. IIUM Journal of Economics and Management, 7(1), 1-25. 
Sekaran, Uma. (2000). Research Methods for Business: A Skill Building Approach. New York: John Wiley \& Sons.

Wienclaw, Ruth A. (2008). Business Strategy \& Policy. Research Starters Business, pp. 1-1, 10. Retrieved March 31, 2009, from http://web.ebscohost.com. 